\title{
INOVASI PEMBELAJARAN BERBASIS TEORI KECERDASAN MAJEMUK UNTUK PENGEMBANGAN PERAN SEKOLAH DI ERA 4.0
}

\author{
Oleh: \\ Panggih Priyambodo (panggihpriyambodo.2019@student.uny.ac.id) \\ Universitas Negeri Yogyakarta
}

\begin{abstract}
ABSTRAK
Era Revolusi Industri 4.0 telah membawa dampak fenomena disrupsi di berbagai bidang kehidupan. Karakteristik generasi muda juga mengalami pergeseran, terutama yang terjadi pada generasi milenial (gen Y) dan generasi Z. Kondisi ini mendorong sekolah sebagai lembaga pendidikan formal untuk menyelenggarakan proses pembelajaran yang mampu menjawab tantangan global. Inovasi dalam proses pembelajaran harus terus dilakukan salah satunya melalui pengembangan kecerdasan majemuk (multiple intelligences) serta pelibatan unsur teknologi pembelajaran. Pengembangan kecerdasan majemuk di dalam proses pembelajaran membutuhkan kreativitas dari para guru dalam memilih dan menetapkan model maupun strategi pembelajaran yang tepat. Instrumen penilaian juga tidak hanya diarahkan pada pengukuran aspek kognitif saja melainkan mencakup keseluruhan aspek kompetensi sebagaimana yang dibutuhkan peserta didik. Pola pembelajaran berbasis pengembangan kecerdasan majemuk akan lebih efektif jika dilakukan dengan mengangkat isyu-isyu maupun permasalahan nyata. Melalui proyek penyelidikan, peserta didik akan terlibat aktif di berbagai bentuk kegiatan belajar sehingga menjadikannya berkesempatan untuk memunculkan berbagai bentuk kemampuan. Proses pembelajaran berbasis pengembangan kecerdasan majemuk diharapkan mampu menumbuhkembangkan kompetensi peserta didik secara menyeluruh. Hasil akhirnya adalah terbentuknya individu-individu adaptif yang mampu bersaing di era revolusi industri 4.0 tanpa harus meninggalkan kultur lokalnya.

Kata Kunci: Revolusi Industri 4.0, Pembelajaran, Kecerdasan Majemuk, Teknologi, Instrumen Penilaian
\end{abstract}

\section{ABSTRACT}

Industrial Revolution Era 4.0 has brought disruption phenomena in various fields of life. The characteristics of the younger generation also experienced a shift, especially those that occurred in the millennial generation (gen Y) and generation Z. This condition encouraged schools as formal educational institutions to organize learning processes that can answer global challenges. Innovations in the learning process must be done continuously, one of them through the development of multiple intelligences and the involvement of learning technology elements. The development of multiple intelligences in the learning process requires the creativity of the teacher in selecting and determining the right models and learning strategies. The assessment instrument is not only directed at measuring cognitive aspects but also covers all aspects of competency as required by students. Learning patterns based on the development of multiple intelligences will be more effective if done by raising issues and real problems. Through an inquiry project, students will be actively involved in various forms of learning activities to make it an opportunity to bring up multiple types of abilities. The learning process, based on the development of multiple intelligences, is expected to be able to develop student competencies as a whole. The final result is the formation of adaptive individuals who are able to compete in the industrial revolution 4.0 era without having to leave their local culture.

Keywords: Industrial Revolution 4.0, Learning, Multiple Intelligences, Technology, Assessment Instrument. 


\section{PENDAHULUAN}

Sekolah harus mampu menjadi ujung tombak dalam hal penyiapan generasi muda masa depan yang adaptif terhadap perkembangan zaman. Guru sebagai pembimbing (pamong) sekaligus fasilitator dalam kegiatan pembelajaran juga berkewajiban untuk menganalisis tingkat kemampuan maupun perkembangan peserta didiknya. Guru diharapkan tidak hanya membelajarkan peserta didik sebagaimana pengalaman mereka terdahulu. Lebih dari itu, guru harus mampu memandang ke depan agar memahami fenomena dan tantangan yang kelak akan dihadapi peserta didiknya. Sekolah sebagai lembaga pendidikan formal dituntut untuk selalu tanggap dalam menyikapi tuntutan perkembangan zaman dan juga dinamika sosial yang terjadi di masyarakat.

Perkembangan ilmu pengetahuan dan teknologi telah membawa banyak perubahan besar dalam sistem sosial masyarakat. Dinamika pergerakan serta perkembangan global yang begitu cepat telah membawa tuntutan-tuntutan baru yang harus dihadapi bangsa-bangsa di dunia. Negara-negara di dunia kini berlomba untuk menciptakan generasi yang kompetitif, menguasai pengetahuan dan teknologi, berkarakter dan memiliki daya juang yang handal untuk mampu bertahan pada persaingan global. Indikasi keberhasilan dari sebuah generasi adalah kemampuannya untuk menghasilkan terobosan maupun inovasi yang bernilai guna bagi masyarakat. Oleh karena itu, penyelenggaraan pendidikan terutama di lembaga pendidikan formal (sekolah) harus terus dikembangkan agar mampu menjawab setiap tantangan yang ada.

Perkembangan dunia selalu diiringi dengan kemunculan generasi baru di setiap rentang masa. Berdasarkan runtutan sejarah, terdapat dua generasi yang kemunculannya identik dengan perkembangan teknologi. Kedua generasi tersebut adalah generasi Generasi Y (Gen Y)/Gen Net/Millennials dan Generasi Z. Generasi milenial merupakan generasi terbaru untuk memasuki dunia kerja, di mana generasi ini lahir antara tahun 1980 hingga 2000 (Smith, T.J. \& Nichols, T., 2015: 39). Sedangkan Generasi $\mathrm{Z}$ adalah generasi yang lahir setelah tahun 2000 hingga saat ini (Ali, H. \& Purwandi, L., 2016: 13). Beberapa karakteristik dari Generasi Y dan Generasi Z adalah sebagai berikut, (1) Generasi Y, dengan ciri-ciri: (a) telah terbiasa mendapatkan akses informasi secara cepat, (b) pola pikir dan karakternya memunculkan ide-ide visioner dan inovatif sehingga dapat melahirkan generasi yang berpengetahuan dan menguasai IPTEK, (c) keseimbangan gaya hidup dan pekerjaan dianggap sebagai hal yang sangat penting, 
serta (d) orientasi pencarian pekerjaan adalah yang dapat menunjang gaya hidup; dan (2) generasi $Z$, dengan ciri-ciri: (a) pola pikir yang "serba ingin instan", (b) kecenderungan untuk bergantung pada teknologi, bahkan memilih popularitas dari media sosial yang digunakan, (c) tidak menyukai aturan yang kaku, cenderung berfikir kreatif dan terbuka, serta (d) generasi post-millennial sangat mudah berkomentar, sehingga membutuhkan pengarahan khusus untuk memahami etika dalam hidup bermasyarakat (Pusat Inovasi dan Kajian Akademik UGM, 2018).

Keberadaan setiap generasi menyiratkan karakteristik khas dan sifatsifat khusus yang harus dipahami oleh para pendidik di setiap lembaga pendidikan. Pemahaman tersebut dijadikan dasar dalam menentukan spesifikasi kebutuhan maupun perencanaan pembelajaran tertentu secara tepat sasaran. Jika tidak, proses pembelajaran menjadi kurang bermakna dan kurang berdaya guna yang tentu akan mengancam tumbuh kembang dari peserta didik itu sendiri.

Adaptasi penggunaan teknologi di dalam pembelajaran serta penerapan beragam model pembelajaran inovatif sangat diperlukan di era kemajuan ilmu pengetahuan dan teknologi. Prasetyo, B. \& Trisyanti, U. (2018: 22) menyatakan bahwa saat ini, globalisasi telah memasuki era baru yang bernama Revolusi Industri 4.0., di mana secara fundamental mengakibatkan berubahnya cara manusia berpikir, hidup, dan berhubungan satu dengan yang lain sehingga akan mendisrupsi berbagai aktivitas manusia dalam berbagai bidang, tidak hanya dalam bidang teknologi saja, namun juga bidang yang lain seperti ekonomi, sosial, dan politik. Globalisasi sendiri dimaknai sebagai sebuah kecenderungan umum berupa terintegrasinya kehidupan masyarakat domestik/lokal ke dalam komunitas global di berbagai bidang (Arfani, R.N., 2004: 1). Beberapa prinsip dari desain industri 4.0 adalah sebagai berikut: Pertama, interkoneksi (sambungan), yaitu kemampuan mesin, perangkat, sensor dan orang untuk terhubung dan berkomunikasi satu sama lain melalui Internet of Things (IoT) atau Internet of People (IoP), di mana prinsip ini membutuhkan kolaborasi, keamanan dan standar. Kedua, transparansi informasi, yaitu kemampuan sistem informasi untuk menciptakan salinan virtual dunia fisik dengan memperkaya model digital dengan data sensor termasuk analisis data dan penyediaan informasi. Ketiga, bantuan teknis, meliputi: (1) kemampuan sistem bantuan untuk mendukung manusia dengan menggabungkan dan mengevaluasi informasi secara sadar untuk membuat keputusan yang tepat dan memecahkan masalah mendesak dalam waktu singkat, 
(2) kemampuan sistem untuk mendukung manusia dengan melakukan berbagai tugas yang tidak menyenangkan, terlalu melelahkan, atau tidak aman, dan (3) kemampuan sistem meliputi bantuan visual dan fisik. Keempat, keputusan terdesentralisasi, yaitu merupakan kemampuan sistem fisik maya untuk membuat keputusan sendiri dan menjalankan tugas seefektif mungkin (Hermann, et al., dalam Yahya, M., 2018: $3)$.

Tantangan era 4.0 dan karakteristik generasi masa kini mendorong inovasi dan pengembangan proses pembelajaran secara berkelanjutan. Salah satu inovasi yang dapat dilakukan adalah penyelenggaraan pembelajaran berbasis kecerdasan majemuk (Multiple Intelligences). Pengembangan kecerdasan majemuk atau kecerdasan jamak pada peserta didik sekaligus dengan pelibatan unsur teknologi yang relevan diharapkan mampu mewujudkan program pendidikan yang sesuai dengan perkembangan zaman maupun tantangan global.

\section{RUMUSAN MASALAH}

Rumusan masalah dalam kajian ini meliputi: (1) sekolah sebagai lembaga pendidikan formal memiliki tugas dan tanggung jawab dalam membekali peserta didik dengan beragam kompetensi sesuai kebutuhan di era revolusi industri 4.0; (2) globalisasi pada era revolusi industri 4.0 telah membawa dampak fenomena disrupsi di berbagai bidang kehidupan sehingga menuntut peningkatan keterampilan generasi penerus secara komprehensif; dan (3) proses pembelajaran harus memperhatikan karakteristik dan kecenderungan peserta didik terutama untuk generasi milenial dan generasi $\mathrm{Z}$ yang salah satunya dapat dicapai melalui pengembangan kecerdasan majemuk (multiple intelligences) dan pelibatan teknologi pembelajaran.

\section{PEMBAHASAN}

\section{Pembelajaran di Era 4.0}

Pembelajaran di era revolusi industri 4.0 diarahkan pada pengembangan ragam jenis keterampilan (skills) kompetitif untuk meningkatkan daya saing bangsa. Penerapan pendekatan saintifik yang meliputi kegiatan mengamati, menanya, mengumpulkan informasi atau bereksperimen, mengasosiasi, \& mengkomunikasikan sebagaimana ketentuan di dalam standar proses harus lebih diperkuat. Peserta didik juga harus dibiasakan dengan penerapan pembelajaran berbasis pengembangan HOTS (Higher Order Thinking Skills) melalui pendekatan student-centered learning. Semua hal tersebut merupakan bentuk upaya dalam membekali peserta didik dengan kemampuan abad 21. Zubaidah, S. (2016: 3) menyatakan bahwa menurut US-Based 
Partnership for 21st Century Skills, kompetensi yang diiperlukan di abad 21 meliputi empat hal yang dikenal sebagai "The 4C", yaitu Communication, Collaboration, Critical Thinking, dan Creativity. Untuk mendukung pengembangan keempat jenis kemampuan tersebut membutuhkan modifikasi dalam pendidikan, yaitu: (1) sistem pendidikan harus menerapkan modifikasi metode penilaian alternatif yang dapat menumbuhkan kepercayaan diri peserta didik dan sekaligus mengurangi kecemasannya. Salah satunya dengan penerapan penilaian berbasis perkerjaan proyek formatif, (2) optimalisasi investasi sumber daya manusia dengan cara memberikan dukungan, kepercayaan, dan peluang bagi guru untuk merasa nyaman dalam menjalankan profesinya dan sekaligus berkesempatan luas untuk mengembangkan pengetahuan berbasis keterampilan bidang, (3) memberikan keleluasaan bagi guru untuk menerapkan pembelajaran yang berpusat pada peserta didik sehingga dapat menginternalisasi berbagai pengalaman belajar yang substansial, dan (4) pemangku kepentingan seperti pemerintah, pengawas, administrator dan termasuk guru harus mampu menginisiasi terjadinya perubahan sistem pendidikan dengan menekankan pada advokasi (penumbuhkembangan kesadaran \& motivasi) maupun pengembangan keterampilan komunikasi, berpikir kritis, dan pemecahan masalah pada peserta didik (Carlgren, T., 2013: 7172).

Perkembangan teknologi merupakan motor penggerak terjadinya perkembangan zaman sebagaimana yang telah sampai pada era revolusi industri 4.0. Perkembangan teknologi berdampak pada perluasan jejaring komunikasi antar manusia di dunia dan juga fenomena disrupsi di berbagai bidang kehidupan. Disrupsi merupakan perubahan yang sangat mendasar sebagaimana telah terjadi di berbagai industri, seperti musik, suratmenyurat, media cetak, dan transportasi publik seperti taksi (Eoy-Gardiner, et al., 2017: 2). Fenomena disrupsi ini tidak hanya terjadi dalam dunia bisnis saja, namun telah meluas dalam bidang lainnya seperti pendidikan, pemerintahan, budaya, politik, dan hukum (Prasetyo, B. \& Trisyanti, U., 2018: 24).

Pendidikan masa kini harus mampu menjawab tantangan global dengan mengupayakan terbentuknya generasi yang adaptif. Yuliati, Y. \& Saputra, D.S. (2019: 169) menyatakan bahwa era revolusi industri 4.0 menuntut sumber daya manusia yang melek sains, melek teknologi, mampu berpikir kritis, mampu bekerja sama, kreatif, dan inovatif dengan rasa percaya diri yang tinggi. Untuk itu, Yuliati \& Saputra juga menjelaskan bahwa 
pendidikan 4.0 menghendaki pembelajaran yang sesuai dengan kebutuhan peserta didik (bukan sekadar transfer pengetahuan) serta optimalisasi teknologi dalam pembelajaran.

Pemerintah sendiri juga telah mengupayakan beberapa hal terkait persiapan dalam menghadapi kenyataan disrupsi. Satya, V.E. (2018: 21) menyatakan bahwa dalam rangka menyongsong fenomena disrupsi di era 4.0, Indonesia telah mengadaptasi upaya di antaranya adalah peningkatan kompetensi sumber daya manusia melalui program link and match antara pendidikan dengan industri. Peserta didik harus memiliki kemampuan yang menyeluruh dengan basis pada penguasaan teknologi informasi.

Posisi dan peran guru maupun peserta didik dalam pembelajaran di era 4.0 tentu berbeda dengan posisi dan perannya di masa lalu. Trilling \& Hood (1999: 10) menjelaskan tentang perbedaan mendasar antara prinsip dan gaya belajar di abad pertengahan dengan gaya belajar di abad industrial.

Tabel 1.

Perbedaan Belajar Abad Pertengahan dan Abad Industrial

\begin{tabular}{cc}
\hline Industrial Age & Knowledge Age \\
Teacher as Director & Teacher as Facilitator, Guide, Consultant \\
Teacher-asKnowledge Source & Teacher as Co-learner \\
Curriculum-Directed Learning & Student-Directed Learning \\
Time-slotted, Rigidly Scheduled Learning & Open, Flexible, On-Demand Learning \\
Primarily Fact-Based & Primarily Project \& Problem-Based \\
Theoretical, Abstract & Real-World, Concrete \\
Principles \& Survey & Actions \& Reflections \\
Drill \& Practice & Inquiry \& Design \\
Rules \& Procedures & Discovery \& Invention \\
Competitive & Collaborative \\
Classroom-Focused & Community-Focused \\
Prescribed Results & Open-Ended Results \\
Conform to Norm & Creative Diversity \\
Computers as Subject of Study & Computers as Tool for all Learning \\
Static Media Presentations & Dynamic Multimedia Interactions \\
Classroom Bounded Communication & Worldwide-Unbounded Communication \\
Test-Assessed by Norms & Performance-Assessed by Expert, Mentors, Peers \& Self \\
\hline
\end{tabular}

\section{Pembelajaran Berbasis Kecerdasan Majemuk}

Pembelajaran berbasis kecerdasan majemuk (multiple intelligences) memungkinkan peserta didik dapat memperoleh keterampilan yang lengkap. Pembelajaran akan berlangsung menyeluruh yang dapat menjangkau berbagai bentuk kecerdasan baik yang bersifat afektif, kognitif, maupun psikomotorik. Pengembangan kecerdasan majemuk juga sangat membuka peluang bagi penggunaan maupun integrasi teknologi di dalam pembelajaran.

Teori kecerdasan majemuk (multiple intelligences theory) dikembangkan oleh seorang psikolog bernama Howard 
Gardner. Meskipun Gardner telah bekerja bertahun-tahun dalam membangun konsep Multiple Intelligences, teori ini belum juga diperkenalkan sampai bukunya yang berjudul Frames of Mind diterbitkan pada tahun 1983 (Zhou, M. \& Brown, D. 2017: 80). Menurut Gardner, manusia dilahirkan dengan potensi untuk mengembangkan multisiplitas kecerdasan, di mana kesemuanya itu dapat menjadikan manusia menjadi individu yang berkompeten (Pal, H.R., Pal, A. \& Tourani, P., 2004: 183184). Pada mulanya, Gardner mengenalkan tujuh jenis kecerdasan manusia. Namun kemudian, melalui bukunya yang berjudul "Intelligence Reframed" di tahun 1999, Gardner menambahkan dua jenis kecerdasan lagi yaitu kecerdasan naturalistik dan eksistensial.

Tabel 2.

Jenis Kecerdasan dalam Multiple Intelligences Theory

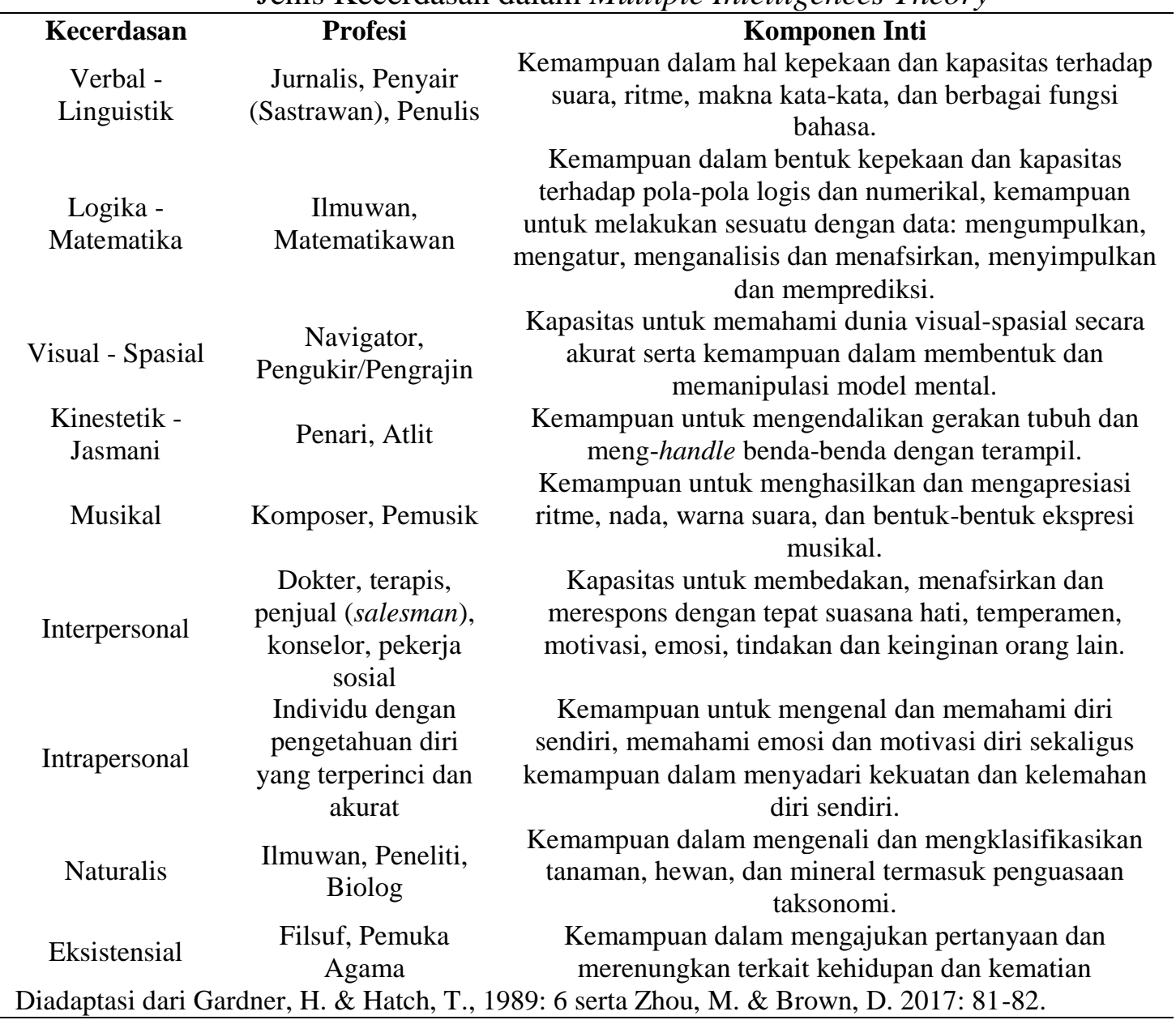

Pengembangan jenis-jenis kecerdasan sebagaimana yang dirumuskan dalam teori kecerdasan majemuk Howard Gardner tidak selalu harus parsial. Guru dapat menyiapkan strategi pembelajaran tertentu untuk melatih dan mengembangkan beberapa jenis kecerdasan sekaligus. Pada prinsipnya, peserta didik dibekali dengan 
ragam jenis kemampuan dan kecerdasan untuk kemudian dikembangkan secara mandiri dalam kehidupan sehari-hari.

Penerapan pembelajaran berbasis kecerdasan majemuk memungkinkan peserta didik dapat menggali dan juga mengenali kemampuan dirinya. Pemahaman terhadap diri sendiri merupakan hal mendasar dalam membangkitkan motivasi serta kemauan peserta didik untuk belajar. Terlebih apabila guru dapat menyajikan kegiatan pembelajaran yang bersesuaian dengan jenis-jenis kecerdasan yang dimiliki tersebut. Hal ini selaras dengan pandangan Ki Hadjar Dewantara bahwa penerapan sistem Among dalam pembelajaran memungkinkan peserta didik mencapai kemerdekaan dalam belajar, di mana lahirnya tidak diperintah, tetapi batinnya memerintah sendiri (Djohar \& Istiningsih, 2017: 2). Yaumi, M. (2015: 190) menyatakan bahwa terkait dengan pelaksanaan pembelajaran berbasis kecerdasan jamak (majemuk), istilah metode, atau strategi mikro, yang juga disebut aktivitas pembelajaran merupakan komponen yang ikut berkontribusi dalam pengembangan kecerdasan jamak (majemuk). Yaumi juga mengutip pendapat Amstrong tahun 2009 dengan menambahkan bahwa strategi pembelajaran yang dimaksud adalah bercerita (storytelling), sumbang pendapat (brainstorming), heuristik, visualisasi, kinestetik, diskografi, simulasi, dan lainlain. Hal penting pertama yang harus dilakukan guru adalah mengenali dan mengidentifikasi tingkat kemampuan (kualitas) peserta didik, kecenderungan kecerdasan yang dimiliki, dan tingkat kesiapan (kemauan) dalam belajar. Hasil identifikasi tersebut kemudian dijadikan dasar dalam menetapkan rencana pembelajaran serta target pencapaiannya.

Pemahaman guru terhadap kondisi tiap-tiap peserta didik harus dilengkapi dengan pemahaman terkait kriteria (indikator) dari setiap jenis kecerdasan. Musfiroh, T. (2010: 1.48) menyatakan bahwa kesemua indikator dalam setiap jenis kecerdasan akan semakin kuat apabila dimunculkan (dalam arti digunakan) untuk mengatasi masalah tertentu atau menciptakan sesuatu yang sesuai. Oleh karena itu, guru harus menetapkan jenis kecerdasan tertentu yang hendak dikembangkan sekaligus dengan kriteriakriteria pencapaiannya.

Kriteria (indikator) dari setiap jenis kecerdasan merupakan acuan dalam merencanakan pembelajaran. Sebagai contoh adalah terkait kecerdasan interpersonal. Guru dapat menguraikan indikator-indikator dari kecerdasan interpersonal tersebut untuk menentukan arah pembelajaran, obyek permasalahan, sekaligus instrumen penilaian yang akan 
digunakan. Pemilihan suatu jenis kecerdasan tertentu juga dapat dikombinasikan dengan jenis kecerdasan lain, semisal kecerdasan interpersonal dapat dikombinasikan dengan kecerdasan visual-spasial, kecerdasan logikamatematika, ataupun jenis kecerdasan lainnya. Contoh kriteria (indikator) kecerdasan interpersonal adalah sebagai berikut: (1) sering didatangi orang untuk dimintai nasihat atau saran, baik di lingkungan tempat kerja maupun di lingkungan tempat tinggal; (2) lebih memilih kegiatan yang membutuhkan kerja tim; (3) cenderung minta tolong atau bicara kepada orang lain ketika menghadapi masalah; (4) memiliki banyak teman; (5) lebih menyukai permainan bersama untuk mengisi waktu; (6) menyukai tantangan untuk mengajar orang lain atau sekelompok orang tentang hal-hal yang dikuasai; (7) menganggap diri sebagai pemimpin atau dianggap pemimpin oleh orang lain; (8) senang atau menikmati berada di tengah keramaian; (9) senang terlibat dalam kegiatan sosial; (10) lebih memilih mengisi waktu malam dengan diskusi daripada sendirian (Diadaptasi dari Musfiroh, T., 2010:7.5).

Pemilihan model maupun strategi pembelajaran dapat dilakukan secara terprogram dan terencana. Dalam konteks pelaksanaan pendidikan di Indonesia, guru dapat mengembangkan berbagai jenis kecerdasan pada peserta didik dengan tetap mengacu pada target pencapaian materi serta bentuk pembelajaran sebagaimana yang dirumuskan di dalam kurikulum. Dalam hal ini, guru membutuhkan daya imajinasi dan kreativitas untuk menyelenggarakan proses pembelajaran. Guru tidak hanya terpaku pada satu metode atau strategi saja, di mana guru dapat selalu mengubah metode presentasi: mulai dari metode lingustik ke metode spasial, lalu ke metode musik, dan seterusnya; kerap mengkombinasikan berbagai kecerdasan secara kreatif (Mushollin, 2009: 232).

Kreasi dalam pembelajaran sangat diperlukan. Guru dapat mengarahkan peserta didik untuk saling bekerjasama mengkaji masalah, menggunakan media pembelajaran, berkomunikasi satu sama lain, menghitung, presentasi, menciptakan gerak tubuh, memodifikasi atau menciptakan produk tertentu, menulis refleksi diri, belajar di alam terbuka, dan lain sebagainya. Dampak lain dari pengembangan kecerdasan majemuk adalah terciptanya lingkungan belajar yang dinamis dan kreatif dari waktu ke waktu namun tetap terkontrol sebagaimana tuntutan kurikulum.

Pencapaian kompetensi melalui pengembangan kecerdasan majemuk akan lebih optimal jika disertai dengan penyajian pengalaman langsung. Suryadi, A. (2007: 
95) mengungkapkan bahwa terdapat dua elemen reformasi pembelajaran untuk meningkatkan efektivitas pembelajaran, yaitu pembaruan pendekatan pembelajaran dan pemanfaatan ICT (Information Communication Technology). Paradigma ini dipandang sangat mendukung pengembangan kecerdasan majemuk dengan pelibatan unsur teknologi pembelajaran. Suryadi menjelaskan bahwa penggunaan teknologi pembelajaran akan mempermudah dan mempercepat kerja peserta didik (mengefisienkan), dan menyenangkan karena peserta didik dapat berinteraksi dengan warna-warna, gambar, suara, video, dan sesuatu yang instan. Dalam konteks pembelajaran sains di era pendidikan 4.0., Yuliati, Y.\& Saputra, D.S. (2019: 170) juga memberikan opsi (rekomendasi) bahwa penerapan pembelajaran STEM merupakan salah satu alternatif karena dapat melatih peserta didik dalam menerapkan pengetahuannya untuk membuat desain sebagai bentuk pemecahan masalah terkait lingkungan melalui pemanfaatan teknologi, sehingga memungkinan peserta didik untuk dilatih menjadi melek sains dan teknologi. Strategi pada pendekatan STEM sendiri sebagaimana yang diuraikan Sunarno, W. (2018: 3-4) adalah sebagai berikut: (1) mengajukan pertanyaan dan mendefinisikan masalah; mengembangkan dan menggunakan model serta merencanakan untuk melakukan investigasi; (3) menganalisis dan menafsirkan data dengan menggunakan matematika, teknologi informasi dan komputer dan berpikir komputasi; (4) membangun eksplanasi dan merancang solusi dan terlibat dalam argumen berdasarkan bukti; serta menyimpulkan, mengevaluasi, dan mengkomunikasikan.

Pendidikan di era 4.0 membutuhkan beberapa modifikasi dan inovasi yang bertolak dari dua sudut pandang, yaitu sudut pandang pendekatan dan sudut pandang penggunaan teknologi. Dalam hal pendekatan, proses pembelajaran dapat mengacu pada pengembangan kecerdasan majemuk (multiple intelligences) dalam rangka membekali peserta didik dengan beragam kemampuan adaptif. Sedangkan dari sudut pandang teknologi, proses pembelajaran dapat mengadopsi beragam bentuk teknologi yang relevan untuk meningkatkan efektivitas dan efisiensi kinerja peserta didik. Proses pembelajaran juga dapat diatur sebagaimana prinsip STEM untuk memudahkan pengembangan kecerdasan majemuk dalam konteks pertalian antara sains, teknologi, lingkungan dan matematika. 


\section{Contoh Pengembangan Kecerdasan Majemuk dalam Pembelajaran dengan Pelibatan Unsur Teknologi}

\begin{tabular}{lll}
\hline Satuan Pendidikan/Kelas & $:$ & SMA/XII \\
Semester & $:$ & Genap \\
Mapel/Materi & $:$ & Biologi/Ekosistem \\
Model Pembelajaran & $:$ & Group Investigation berbasis Proyek \\
Waktu & $:$ & 2 Minggu \\
\hline
\end{tabular}

Langkah umum pembelajaran: (1) peserta didik dalam kelompok mengamati kondisi eksosistem di lingkungan alami (kecerdasan naturalis \& eksistensial); (2) peserta didik melalukan analisis vegetasi dengan metode transek secara berkelompok (kecerdasan logika-matematika \& naturalis); (3) peserta didik mengambil sampel air di lokasi penelitian dan dianalisis dengan perangkat teknologi berupa lasser scanning microscope (kecerdasan kinestetik jasmani); (4) peserta didik dalam kelompok menyusun laporan dan mensintesis hasil investigasi. Penyusunan laporan dilakukan dengan mengkaji teori dari berbagai sumber literatur dengan memanfaatkan teknologi informasi berbasis internet (kecerdasan interpersonal); (5) peserta didik secara berkelompok membuat poster terkait himbauan pelestarian lingkungan dengan aplikasi komputer seperti coral draw \& photoshop (kecerdasan visual-spasial); (6) peserta didik mempresentasikan dan mendiskusikan laporan hasil penelitian (kecerdasan verbal-linguistik); (7) peserta didik membuat refleksi dan evaluasi terkait kekurangan dan kelebihan dari serangkaian kegiatan investigasi yang telah dilakukan (kecerdasan intrapersonal); dan (8) hasil pembelajaran dapat dipublikasikan dalam bentuk vlog atau video tutorial untuk dibagikan di media sosial (kecerdasan verbal \& kecerdasan interpersonal).

\section{Instrumen Penilaian Kecerdasan Majemuk}

Pengembangan instrumen penilaian mengacu pada kriteria-kriteria (indikator) kecerdasan tertentu yang hendak dikembangkan dalam pembelajaran. Hasil penilaian kemudian digunakan untuk memantau perkembangan tiap-tiap peserta didik dari waktu ke waktu untuk merencanakan kegiatan pembelajaran secara berkelanjutan. Arikunto (dalam Aunurrahman, 2009: 208-209) menjelaskan tentang prinsip penting dalam kegiatan evaluasi pembelajaran yang berbasis prinsip triangulasi. Dalam prinsip tersebut terdapat tiga komponen yang saling berhubungan erat, yaitu tujuan, kegiatan pembelajaran atau KBM, dan evaluasi. Begitu juga dengan Sudjana (dalam Rahayu, E.F., 2015: 362) menyatakan bahwa tahapan dalam pelaksanaan belajarmengajar meliputi: (1) pra-instruksional, yaitu tahap yang ditempuh pada saat memulai suatu proses belajar-mengajar; (2) tahap instruksional, yaitu tahap pemberian bahan pelajaran yang dapat diidentifikasikan dengan beberapa kegiatan; dan (3) tahap evaluasi yang merupakan tindak lanjut dari tahap instruksional". Hamid, M.A. (2016: 38) menyatakan bahwa penilaian hasil belajar peserta didik merupakan kegiatan guru yang berkaitan dengan pengambilan 
keputusan tentang pencapaian kompetensi atau hasil belajar peserta didik selama mengikuti proses pembelajaran.

Perumusan tujuan pembelajaran dapat mempengaruhi pemilihan model maupun metode pembelajaran yang akan digunakan. Pemilihan model atau metode pembelajaran dipengaruhi oleh tujuan pembelajaran dan sekaligus mempengaruhi pemilihan teknik evaluasi dan penilaian. Begitu seterusnya sebagaimana alur keterhubungan dari arah yang lain.

Proses penilaian tidak bisa dilepaskan dari kegiatan pembelajaran. Penilaian merupakan komponen penting dalam sistem pendidikan karena mencerminkan perkembangan atau kemajuan hasil pendidikan lebih jauhnya lagi tentang mutu pendidikan dalam periode tertentu (Khiyarusoleh, U. \& Trisnawati, E., 2017:768). Dalam konteks pembelajaran dengan basis pengembangan kecerdasan majemuk, proses penilaian berguna dalam mengidentifikasi kecendrungan jenis-jenis kecerdasan yang menonjol dari tiap-tiap peserta didik dan sekaligus memberi pertimbangan terkait tema masalah maupun kegiatan pembelajaran yang akan diselenggarakan.

Guru dapat menyiapkan beragam bentuk teknik penilaian untuk pembelajaran berbasis pengembangan kecerdasan majemuk. Berbagai teknik penilaian seperti observasi, tes, atau bahkan kuesioner dapat dimanfaatkan oleh guru. Pengembangan instrumen penilaian berbasis kecerdasan majemuk dapat dilakukan dengan mengacu pada prinsip-prinsip sebagaimana yang digunakan dalam mengembangkan instrumen penelitian. Proses ini juga dapat dilakukan secara terprogram dari waktu ke waktu seraya mengamati detail perkembangan yang telah dicapai tiap-tiap peserta didik. Khiyarusoleh, U. \& Trisnawati, E. (2017: 769) menjelaskan tentang tahapan pengembangan instrumen sebagaimana mengacu pada model 4-D (Four D Model), yang meliputi: Tahap 1: pendefinisian (define). Tujuan tahap ini adalah menetapkan dan mendefinisikan syarat-syarat yang diperlukan dalam pembuatan instrumen. Kegiatan yang dilakukan dalam tahap ini adalah analisis ujung depan, analisis peserta didik, analisis tugas (task analysis), analisis topik dan merumuskan tujuan pembuatan instrumen maupun tujuan pembelajaran. Tahap 2: perancangan (design). Tahap ini bertujuan merancang atau mendesain instrumen kecerdasan majemuk, sehingga diperoleh pengembangan instrumen yang baik sesuai kriteria dan kaidah-kaidah pembuatannya. Tahap 3: pengembangan (develop). Tujuan dari tahap ini adalah untuk menghasilkan draft instrumen penilaian yang telah direvisi berdasarkan masukan para ahli dan data yang diperoleh dari uji coba. Kegiatan pada tahap ini dapat dilengkapi dengan 
validasi instrumen penilaian oleh pakar/ahli diikuti dengan revisi dan uji coba instrumen dengan peserta didik yang sesungguhnya. Tahap 4: penggunaan atau penyebaran (disseminate). Proses diseminasi merupakan suatu tahap akhir pengembangan. Tahap diseminasi dilakukan untuk mempromosikan produk pengembangan agar bisa diterima pengguna, baik individu, suatu kelompok, atau sistem. Produsen dan distributor harus selektif dan bekerja sama untuk mengemas materi dalam bentuk yang tepat.

Pengembangan instrumen pembelajaran identik dengan prinsipprinsip yang berlaku pada pengembangan instrumen penelitian pada umumnya. Firdaos, R. (2016: 382-383) menyatakan bahwa dalam konteks penelitian dalam rangka pengembangan instrumen, peneliti terlebih dahulu menentukan variabel yang akan dikembangkan. Tahap selanjutnya adalah proses pembuatan konstruk, dimensi, dan indikator variabel. Firdaos menjelaskan bahwa di antara tujuan terbentuknya konstruk, dimensi dan indikator adalah, di samping memastikan terhadap sejumlah teori yang mendasarinya, juga merupakan media untuk mempermudah serta memperjelas dalam membuat formulasi sejumlah butir item yang akan dikembangkan. Prinsip ini juga dapat diadopsi dalam hal pengembangan instrumen pembelajaran berbasis kecerdasan majemuk. Guru terlebih dahulu dapat menentukan jenis kecerdasan yang akan dikembangkan berdasarkan pertimbangan terkait kondisi dan kebutuhan peserta didik. Tahap selanjutnya adalah pembuatan atau penyusunan konstruk, dimensi, dan rumusan indikator-indikator pencapaiannya. Dalam hal ini, guru dituntut untuk dapat memahami konsep maupun definisi operasional dari setiap jenis kecerdasan sebagaimana yang dirumuskan dalam teori multiple intelligences. Berdasarkan prinsip-prinsip tersebut, pengembangan instrumen penilaian berbasis kecerdasan majemuk dapat mengacu pada tahapan sebagai berikut. Pertama, penentuan variabel pembelajaran. Dalam hal ini, variabel yang digunakan adalah kecerdasan majemuk. Kedua, penentuan dimensi/aspek pembelajaran dengan mengacu pada dimensi tiap-tiap jenis kecerdasan. Guru dapat memilih dan menentukan satu atau beberapa jenis kecerdasan untuk dikembangkan pada peserta didik dalam satu waktu tertentu. Ketiga, definisi operasional, yaitu guru menggali konsep serta cakupan dari setiap jenis kecerdasan yang hendak dikembangkan dalam pembelajaran. Keempat, perumusan indikator. Guru dapat menyusun rumusan indikator dari jenis kecerdasan yang akan dikembangkan dengan berpijak pada literatur ataupun teori 
tertentu. Kelima, tahapan validasi, yaitu guru memvalidasi instrumen yang telah dikembangkan untuk memastikan kemampuannya dalam mengukur aspekaspek ataupun dimensi (ruang lingkup) kecerdasan yang telah ditetapkan. Dalam proses validasi, guru dapat berkoordinasi dengan teman sejawat (kolega) maupun para ahli. Keenam, tahap penerapan, yaitu guru dapat mulai menggunakan instrumen yang telah dikembangkan di dalam proses pembelajaran.

Artikel ini akan memberikan contoh terkait acuan pengembangan instrumen penilaian untuk pembelajaran berbasis kecerdasan majemuk. Jenis kecerdasan yang dipilih adalah kecerdasan interpersonal dan kecerdasan verballinguistik dengan mengacu pada tema pembelajaran sebagaimana yang telah dicontohkan sebelumnya. Selain kedua jenis kecerdasan tersebut, pada dasarnya guru dapat mengembangkan instrumen untuk jenis kecerdasan yang lain sesuai dengan kebutuhan. Gambaran terkait pengembangan instrumen penilaian berbasis kecerdasan interpersonal dan kecerdasan verbal-linguistik ditampilkan pada tabel berikut.

Tabel 3.

Contoh Pengembangan Instrumen Penilaian dengan Teknik Observasi Berbasis Kecerdasan Interpersonal dan Kecerdasan Verbal-Linguistik

\begin{tabular}{lll}
\hline $\begin{array}{l}\text { Variabel } \\
\text { Dimensi } \\
\text { Definisi Operasional: }\end{array}$ & $:$ & Kecerdasan Majemuk (multiple intelligences) \\
& $:$ & Kecerdasan Interpersonal \& Kecerdasan Verbal-Linguistik \\
& $:$ & Kecerdasan interpersonal adalah kemampuan untuk \\
& menafsirkan dan merespons suasana hati, emosi, motivasi, dan \\
Kecerdasan Interpersonal & keterampilan komunikasi dan interaksi yang baik, dan juga \\
& kemampuan dalam menunjukkan empati terhadap perasaan \\
& individu lain (Zhou, M.Y. \& Brown, D., 2017: 81). \\
& Kecerdasan verbal/linguistik mengacu pada kemampuan \\
& untuk memahami serta memanipulasi kata-kata dan bahasa. \\
& Kemampuan ini termasuk membaca, menulis, berbicara, dan \\
& bentuk komunikasi verbal dan tertulis lainnya (Zhou, M.Y. \& \\
& Brown, D., 2017: 81). \\
\hline Kecerdasan Verbal-Linguistik &
\end{tabular}

Tabel 4.

Contoh Pengembangan Indikator dan Butir (Item) Pernyataan

\begin{tabular}{|c|c|c|}
\hline $\begin{array}{c}\text { Jenis Kecerdasan } \\
\text { Kecerdasan } \\
\text { Interpersonal }\end{array}$ & $\begin{array}{l}\text { Menyukai kegiatan kerja } \\
\text { tim }\end{array}$ & $\begin{array}{l}\text { Item Pernyataan } \\
\text { Mampu berbagi tugas dengan baik bersama } \\
\text { anggota tim. } \\
\text { Memahami peran dan tugasnya dalam kerja } \\
\text { tim dan menunjukkan perilaku yang } \\
\text { bertanggungjawab. }\end{array}$ \\
\hline
\end{tabular}




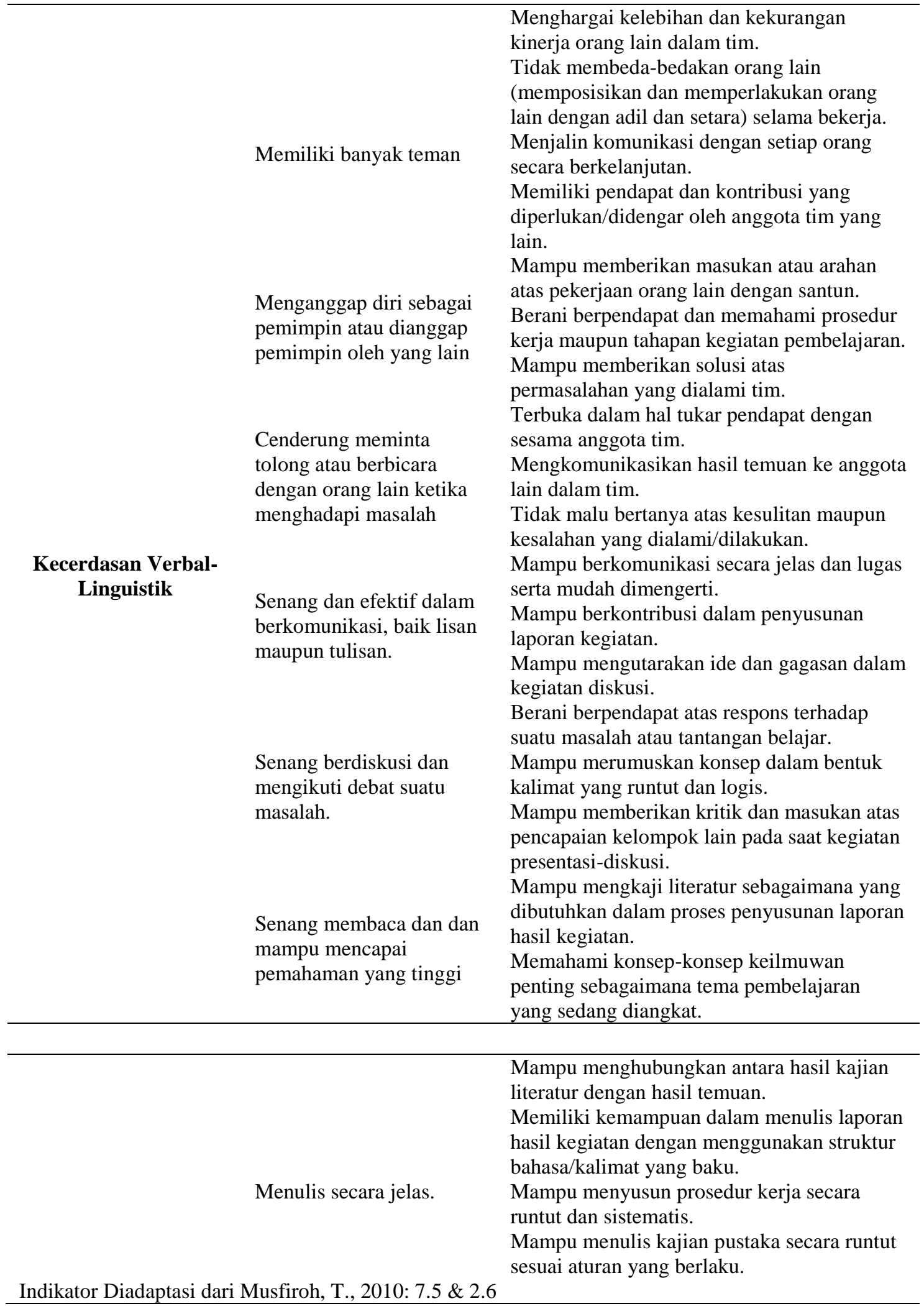

Guru memiliki banyak pilihan terkait teknik serta instrumen penilaian untuk dapat digunakan dalam pembelajaran yang

\begin{tabular}{llr} 
berbasis & \multicolumn{2}{c}{ pengembangan kecerdasan } \\
majemuk. Beragam teknik penilaian & \\
tersebut dapat disesuaikan dengan
\end{tabular}


penekanan aspek kompetensi yang akan diukur, apakah jenis kecerdasan untuk aspek afektif, kognitif, maupun psikomotorik. Proses penilaian juga dapat berupa penilaian dalam bentuk tes ataupun non-tes. Untuk penilaian aspek kognitif, guru dapat menggunakan teknis tes dengan isntrumennya berupa soal uji hasil belajar kognitif. Arah pengukuran dari soal kognitif adalah tingkat penguasaan konsep (penguasan materi) peserta didik setelah mengikuti kegiatan pembelajaran berbasis kecerdasan majemuk ataupun tingkat kemampuannya dalam menggunakan teknologi pembelajaran. Proses penilaian yang menyeluruh akan memberikan sebuah persepsi positif bagi peserta didik. Mereka tidak lagi berpikir bahwa prestasi belajar hanyalah semata-mata tentang penguasaan konsep namun juga melingkupi segala bentuk kecakapan yang dibutuhkan untuk memecahkan masalah. Hasil penilaian dapat memberikan bahan refleksi bagi guru apakah penerapan teori kecerdasan majemuk memberikan dampak yang signifikan terhadap peningkatan prestasi belajar peserta didik.

\section{PENUTUP}

Globalisasi yang telah sampai pada era revolusi industri 4.0 membawa dampak di berbagai bidang kehidupan termasuk pendidikan. Program pendidikan dituntut untuk mampu menyelenggarakan proses pembelajaran yang dapat menjawab tantangan global. Inovasi pendidikan yang dapat dilakukan secara umum mencakup dua aspek, yaitu pembaruan pendekatan serta pelibatan unsur teknologi di dalam pembelajaran. Inovasi dalam hal pendekatan pembelajaran salah satunya melalui pengembangan kecerdasan majemuk (multiple intelligences). Pelibatan unsur teknologi di dalam pembelajaran yang berbasis pengembangan kecerdasan majemuk justru lebih mudah untuk dilakukan. Hal ini dikarenakan model pembelajaran yang digunakan cenderung bersifat dinamis sehingga memungkinkan untuk diterapkannya berbagai bentuk kegiatan yang variatif.

Proses pembelajaran dapat diarahkan pada proses-proses investigasi dan pemecahan masalah berbasis proyek. Dalam penerapannya, kegiatan pembelajaran lebih menekankan pada prinsip kolaborasi dibanding kompetisi. Di awal pembelajaran, guru berkewajiban untuk mengenali dan mengidentifikasi tingkat kemampuan, kecenderungan kemauan (motivasi) belajar, dan karakteristik peserta didik. Guru juga harus mengenali karakteristik maupun gaya belajar generasi kekinian terutama yang menyangkut karakteristik khusus generasi milenial dan generasi Z. Proses pembelajaran juga dapat mengangkat isyuisyu lokal maupun berbagai bentuk 
permasalahan nyata di kehidupan seharihari. Kesemua hal itu dilakukan guna membekali peserta didik dengan aspekaspek kompetensi sebagaimana yang dibutuhkan di abad 21, meliputi Communication, Collaboration, Critical Thinking, dan Creativity. Peserta didik yang telah memiliki bekal kompetensi yang komprehesif diharapkan mampu berkompetisi pada era revolusi industri 4.0 dan juga adaptif dalam menyikapi terjadinya fenomena disrupsi.

\section{DAFTAR PUSTAKA}

Ali, H. \& Purwandi, L. (2016). Indonesia 2020: The Urban Middle-Class Millennials. Jakarta: Alvara Research Center.

Arfani, R.N. (2004). Globalisasi: Karakteristik \& Implikasinya. Ekonomi Politik Digital Journal Al-Manär, 1, 1-13.

Aunurrahman. 2009. Belajar dan Pembelajaran. Bandung: Alfabeta.

Carlgren, T. (2013). Communication, Critical Thinking, Problem Solving: A Suggested Course for All High School Students in the 21st Century. Interchange, 44, 6381, DOI: 10.1007/s10780-0139197-8.

Djohar \& Istiningsih. (2017). Filsafat Pendidikan Ki Hajar Dewantara dalam Kehidupan Nyata. Yogyakarta: Suluh Media.

Eoy, M.-Gardiner, et al. (2017). Era Disrupsi: Peluang dan Tantangan Pendidikan Tinggi Indonesia.
Jakarta: Akademi Ilmu Pengetahuan Indonesia.

Firdaos, R. (2016). Metode Pengembangan Instrumen Pengukur Kecerdasan Spiritual Mahasiswa. Edukasia: Jurnal Penelitian Pendidikan Islam, 11 (2), 377-398, DOI: 10.21043/edukasia.v11i2.1782.

Hamid, M.A. (2016). Pengembangan Instrumen Penilaian Hasil Belajar Siswa Berbasis TIK pada Pembelajaran Dasar Listrik Elektronika. VOLT: Jurnal Ilmiah Pendidikan Teknik Elektro, 1 (1), 37-46.

Khiyarusoleh, U. \& Trisnawati, E. (2017). Implementasi Instrumen Penilaian Kemampuan Bakat Minat Anak Melalui Kecerdasan Majemuk terhadap Penentuan Karir Siswa. Makalah Disampaikan pada Seminar Nasional Hasil Penelitian (SNHP)-VII, di Universitas PGRI Semarang. Diakses dari http://prosiding.upgris.ac.id/index. php/LPPM2017/LPPM2017/paper /viewFile/1990/1979

Musfiroh, T. (2010). Pengembangan Kecerdasan Majemuk. Jakarta: Universitas Terbuka.

Mushollin. (2009). Penerapan Teori Multiple Intelligences Howard Gardner dalam Pembelajaran Pendidikan Agama Islam. Tadrîs, 4 (2), 223-235. DOI: http://dx.doi.org/10.19105/jpi.v4i2 .254 .

Pal, H.R., Pal, A. \& Tourani, P. (2004). Theories of Intelligence. Everyman's Science, XXXIX (3), 181-192.

Prasetyo, B. \& Trisyanti, U. (2018). Revolusi Industri 4.0 dan 
Tantangan Perubahan Sosial. Journal of Proceeding Series: Prosiding SEMATEKSOS 3, 5, 2227.

DOI: http://dx.doi.org/10.12962/j23546 026.y2018i5.4417.

Pusat Inovasi dan Kajian Akademik. (2018). Pendidikan 4.0. Yogyakarta: Universitas gajah Mada. Diakses dari https://pika.ugm.ac.id/id.

Rahayu, E.F. (2015). Manajemen Pembelajaran Dalam Rangka Pengembangan Kecerdasan Majemuk Peserta Didik. Manajemen Pendidikan, 24 (5), 357-366.

Satya, V.E. (2018). Strategi Indonesia Menghadapi Industri 4.0. Info: Kajian Singkat terhadap Isu Aktual dan Strategis DPR RI, X (9), 1924.

Smith, T.J. \& Nichols, T. (2015). Understanding the Millennial Generation. Journal of Business Diversity, 15 (1), 39-47, DOI: 10.4236/iim.2012.46046.

Sunarno, W. (2018, Juli). Peran Pendidik dan Ilmuwan Sains dalam Menyongsong Revolusi Industri 4.0. Makalah disampaikan pada Seminar Nasional Pendidikan Fisika IV, di Program Studi Pendidikan Fisika, FKIP, Universitas PGRI Madiun. http://prosiding.unipma.ac.id/

Suryadi, A. (2007). Pemanfaatan ICT dalam Pembelajaran. Jurnal Pendidikan Terbuka dan Jarak Jauh, 8 (1), 83-98.

Trilling B. \& Hood, P. (1999). Learning, Technology, and Education Reform in the Knowledge Age or "We're Wired, Webbed, and
Windowed, Now What?'. Educational Technology, 39 (3), 125.

Diakses dari https://www.wested.org/online_pu bs/learning technology.pdf

Yahya, M. (2018, Maret). Era Industri 4.0: Tantangan dan Peluang Perkembangan Pendidikan Kejuruan Indonesia. Makalah disampaikan pada Pidato Pengukuhan Penerimaan Jabatan Professor Tetap dalam Bidang Ilmu Pendidikan Kejuruan, di Fakultas Teknik Universitas Negeri Makassar. eprints.unm.ac.id

Yaumi, M. (2015). Desain Strategi Pembelajaran untuk Mengembangkan Kecerdasan Verbal-Linguistik Peserta Didik. Auladuna, 2 (1), 185-200.

Yuliati, Y. \& Saputra, D.S. (2019). Pembelajaran Sains di Era Revolusi Industri 4.0. Jurnal Cakrawala Pendas, 5 (2) , 167171.

DOI:

http://dx.doi.org/10.31949/jcp.v5i 2.1389

Zhou, M.Y. \& Brown, D. (2017). Educational Learning Theories. University System of Georgia: Galileo Open Learning Materials.

Zubaidah, S. (2016, Desember). Keterampilan Abad Ke-21: Keterampilan yang Diajarkan melalui Pembelajaran. Makalah disampaikan pada Seminar Nasional Pendidikan, di Program Studi Pendidikan Biologi STKIP Persada Khatulistiwa. 